\title{
Demonstration of sympathetic nerve innervation in a patient with takotsubo cardiomyopathy using single- photon emission CT
}

\author{
Yukinori Ikegami, Yukihiko Momiyama
}

Department of Cardiology, National Hospital Organization, Tokyo Medical Center, Tokyo, Japan

\section{Correspondence to} Dr Yukinori Ikegami, y.ikegami@cpnet.med.keio.ac.jp

Accepted 2 April 2017

\section{DESCRIPTION}

A 16-year-old male patient with anorexia nervosa was admitted to our hospital because of unconsciousness. He was in hypoglycaemic shock, with a serum glucose level of $40 \mathrm{mg} / \mathrm{dL}$, and recovered consciousness after a venous injection of glucose. The patient's systolic blood pressure remained $<70 \mathrm{~mm} \mathrm{Hg}$ after he recovered consciousness. A 12-lead ECG showed Q waves and ST segment elevation in the precordial leads, and echocardiography showed hypokinesis of the midventricle and apex. Next, we performed coronary angiography, which revealed the absence of stenosis of the coronary arteries. Left ventriculography showed findings typical of takotsubo cardiomyopathy, apical ballooning with akinesis of the midventricle and apex and hyperkinetic basal segments (figure 1). 201Tl and iodofiltic acid (123)I-dual cardiac single-photon emission CT (SPECT) (figure 2A,B) at 1 week showed the absence of perfusion defect and fatty acid metabolism abnormality at the apex. Metaiodobenzylguanidine cardiac SPECT (figure 2C) at 2 weeks showed that sympathetic nerve innervation had occurred in the same area as the akinetic midventricle and apex. Echocardiography indicated complete recovery of

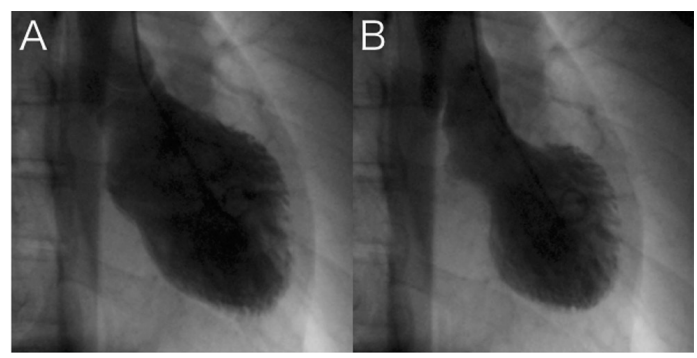

Figure 1 (A) Diastolic phase of left ventriculography. (B) Systolic phase of left ventriculography showing akinesis of the midventricle and apex.

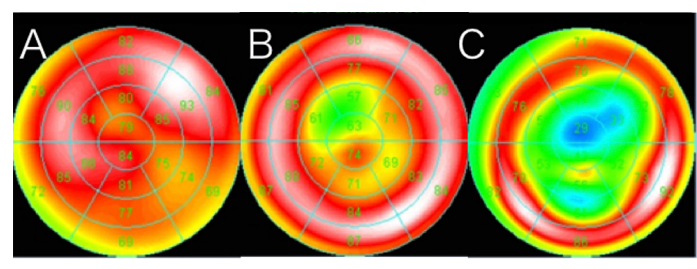

Figure 2 (A and B) 201Tl and iodofiltic acid (123) I-dual cardiac single-photon emission CT (SPECT) at 1 week showing the absence of perfusion defect and fatty acid metabolism abnormality at the apex. (C) Metaiodobenzylguanidine cardiac SPECT at 2 weeks showing sympathetic nerve innervation in the midventricle and apex.

cardiac wall motion 40 days after admission. In summary, the multiple SPECT images suggested that sympathetic nerve innervation is one of the leading pathophysiologies of takotsubo cardiomyopathy in the subacute phase.

\section{Learning points}

- Sympathetic nerve innervation is one of the leading pathophysiologies of takotsubo cardiomyopathy in the subacute phase.

- Hypoglycaemic shock can lead to takotsubo cardiomyopathy.

Contributors $\mathrm{YI}$ and $\mathrm{YM}$ were involved in diagnostic process, review of the literature and drafting of the manuscript.

Competing interests None declared.

Patient consent Obtained.

Provenance and peer review Not commissioned; externally peer reviewed.

(c) BMJ Publishing Group Ltd (unless otherwise stated in the text of the article) 2017. All rights reserved. No commercial use is permitted unless otherwise expressly granted.
Copyright 2017 BMJ Publishing Group. All rights reserved. For permission to reuse any of this content visit http://group.bmj.com/group/rights-licensing/permissions.

BMJ Case Report Fellows may re-use this article for personal use and teaching without any further permission.

Become a Fellow of BMJ Case Reports today and you can:

- Submit as many cases as you like

- Enjoy fast sympathetic peer review and rapid publication of accepted articles

- Access all the published articles

- Re-use any of the published material for personal use and teaching without further permission

For information on Institutional Fellowships contact consortiasales@bmjgroup.com

Visit casereports.bmj.com for more articles like this and to become a Fellow 